\title{
Gold-doping of carbon-supported palladium improves reduction catalysis
}

\author{
Yu-Lun Fang a, Kimberly N. Heck a, Zhun Zhao a, Lori A. Pretzer b, Neng Guo c, Tianpin Wu c, Jeffrey \\ T. Millerd, Michael S. Wong a,b,e,f,* \\ a Department of Chemical and Biomolecular Engineering, Rice University, 6100 S. Main Street, Houston, TX 77005, USA \\ b Department of Chemistry, Rice University, 6100 S. Main Street, Houston, TX 77005, USA \\ c Chemical Sciences and Engineering Division, Argonne National Laboratory, 9700 S. Cass Avenue, Argonne, IL 60439, USA \\ d Department of Chemical Engineering, Purdue University, 480 Stadium Mall Drive West Lafayette, IN 47907, USA \\ e Department of Civil and Environmental Engineering, Rice University, 6100 S. Main Street, Houston, TX 77005, USA \\ ${ }^{\mathrm{f}}$ Department of Materials Science and NanoEngineering, Rice University, 6100 S. Main Street, Houston, TX 77005, USA
}

\section{A R T I C L E I N F O}

\section{Article history:}

Received 28 May 2016

Accepted 14 August 2016

Published 5 October 2016

\section{Keywords:}

Bimetallic catalyst

Palladium

Gold

Nanostructures

X-ray absorption spectroscopy

Extended X-ray absorption fine structure

Hydrodechlorination

Trichloroethene

\begin{abstract}
A B S T R A C T
Bimetallic palladium-gold (PdAu) catalysts have better catalytic performance than monometallic catalysts for many applications. PdAu catalysts with controlled nanostructures and enhanced activities have been extensively studied but their syntheses require multiple and occasionally complicated steps. In this work, we demonstrated that supported PdAu catalysts could be simply prepared by doping a supported Pd catalyst with gold through wet impregnation and calcination. Resulting $\mathrm{PdAu}$-on-carbon $(\mathrm{PdAu} / \mathrm{C})$ catalysts were tested for the room-temperature, aqueous-phase hydrodechlorination of trichloroethene. The most active PdAu/C catalyst (Pd $1.0 \mathrm{wt} \%$, Au $1.1 \mathrm{wt} \%$, dried/air/ $\mathrm{H}_{2}$ process) had an initial turnover frequency (TOF) of $34.0 \times 10^{-2} \mathrm{molTcE}_{\mathrm{Tol}} \mathrm{mod}^{-1} \mathrm{~s}^{-1}$, which was $>15$ times higher than monometallic Pd/C (Pd $1.0 \mathrm{wt} \%$, initial TOF of $2.2 \times 10^{-2} \mathrm{~mol}_{\text {TCE }}$ mol $_{P^{-1}} \mathrm{~s}^{-1}$ ). Through X-ray absorption spectroscopy, the gold kept Pd from oxidizing under calcination at $400{ }^{\circ} \mathrm{C}$. Probable nanostructure evolution pathways are proposed to explain the observed catalysis.
\end{abstract}

(C) 2016, Dalian Institute of Chemical Physics, Chinese Academy of Sciences. Published by Elsevier B.V. All rights reserved.

\section{Introduction}

Palladium-gold ( $\mathrm{PdAu}$ ) catalysts have been investigated for several decades; like other bimetallic catalysts, the PdAu system attracts researchers' interest due to better catalytic activity, selectivity, and stability than monometallic catalysts in various reactions [1-4]. The explanation of bimetallic enhancement for PdAu catalysts has been attributed to two major effects: (1) the geometric effect, in which specific atomic ensem- bles are the most active sites [2,3,5-10], and (2) the electronic effect, in which interaction among surrounding atoms gives rise to electron density dislocation [11-15]. Nanoscale local atomic structures of bimetallic PdAu catalysts are crucial to catalytic activity $[1,4]$. Benefiting from the advances of nanoscale science, researchers now have the ability to understand and control the relationships between nanostructures and catalytic performance of catalysts. For PdAu catalysts, two major types of nanostructures have been extensively investigated: (1) the

\footnotetext{
* Corresponding author. Tel: +1-713-3483511; Fax:+1-713-3485478; E-mail: mswong@rice.edu This work was supported by the National Science Foundation, United States (EEC-0647452) and the Welch Foundation (C-1676). DOI: 10.1016/S1872-2067(16)62530-5 | http://www.sciencedirect.com/science/journal/18722067 | Chin. J. Catal., Vol. 37 , No. 10, October 2016
} 
core-shell structure, in which one metal forms an inner core surrounded by the other metal as an outer shell [16-22], and (2) the alloy structure, in which the metal atoms are randomly distributed $[17,19,22]$.

As a model catalyst, Pd-decorated $\mathrm{Au}$ nanoparticles (Pd-on-Au NPs) have been studied by our group for a variety of aqueous phase reactions, including hydrodechlorination reactions [4,23-29], glycerol oxidation [30-32], nitrophenol reduction [28], and nitrite reduction [33]. These catalysts often have orders-of-magnitude better activity then monometallic Pd catalysts, and also show resistance to deactivation from common catalyst poisons [25]. Supported PdAu catalysts also show promise for treating chloroform-contaminated groundwater [34,35].

While PdAu systems have been widely researched at the lab scale, there remains a gap between fundamental research and real-world applications for PdAu catalysts. Colloidal PdAu NP catalysts with uniform nanostructures have been synthesized by using reducing agents in the presence of stabilizers such as ligands [36,37], polymers [16,38,39], or dendrimers [19,21]. For potential real-world applications, they have been immobilized directly onto solid supports [40-42], or entrapped into support matrices via sol-gel chemistry $[20,43,44]$. However, such colloidal syntheses may be only practical on a laboratory scale because of scale-up difficulties, and the additional removal of surface stabilizers and solvents. To avoid these problems, researchers have investigated direct synthesis of PdAu NPs on supports. Monnier and coworkers $[45,46]$ prepared supported $\mathrm{Au}$-shell/Pd-core catalysts by electroless deposition (ED) to obtain core-shell bimetallic nanostructures at room temperature without stabilizers, but a special setup of ED bath (including choice of metal salts, reducing agents, and $\mathrm{pH}$ values) is necessary. A synthetic route using processes commonly used in industrial catalyst manufacture is more desirable $[47,48]$. Hutchings and coworkers $[49,50]$ have shown that supported $\mathrm{PdAu}$ catalysts containing Pd-shell/Au-core domains of varying sizes are formed from conventional preparation steps (impregnation, drying, calcination, and reduction).

In this work, we investigated the effect of adding gold to commercially available supported Pd catalysts. We impregnated $\mathrm{Au}$ salt on a carbon-supported Pd catalyst, then treated it with a series of common industrial processes such as drying, calcination, and reduction. Catalysts were characterized with inductively coupled plasma spectrometry (ICP), transmission electron microscopy (TEM), and X-ray absorption spectroscopy (XAS). We tested the activity of the catalysts for the room-temperature, aqueous-phase hydrodechlorination (HDC) of trichloroethene (TCE), which converts TCE to ethane using hydrogen as a reductant. Results showed that activity could be improved by adding Au to commercially available supported Pd catalysts through commonly used catalyst preparation techniques.

\section{Experimental}

\subsection{Catalyst preparation and treatments}

All types of carbon-supported $\mathrm{PdAu}$ catalysts $(\mathrm{PdAu} / \mathrm{C})$ were prepared by adding Au salt to commercial Pd-on-carbon (Pd/C, 1 wt\% Pd, Alfa Aesar) catalysts, then subjecting them to different treatments, as illustrated in Scheme 1. Pd/C powder was first pretreated by calcination in $100 \mathrm{ml} / \mathrm{min}$ air (breathing quality, Matheson) at $400{ }^{\circ} \mathrm{C}$ for $3 \mathrm{~h}$. The sample was then cooled to room temperature in flowing air, followed by reduction in flowing hydrogen gas (100 ml/min, 99.99\%, Matheson) at $400{ }^{\circ} \mathrm{C}$ for $3 \mathrm{~h}$, then cooled to room temperature in flowing hydrogen gas. For each batch, $2 \mathrm{~g} \mathrm{Pd} / \mathrm{C}$ powder was dispersed in a mixture of 4-5 mL Nanopure water (>18.0 M $\Omega$-cm, Barnstead NANOpure Diamond) and $0.2 \mathrm{~mL}$ isopropanol ( $>95 \%$, ACS reagent, Fisher, added to aid in dispersing the $\mathrm{Pd} / \mathrm{C}$ powder) at room temperature $\left(22 \pm 2{ }^{\circ} \mathrm{C}\right)$, followed by ultrasonication for $1 \mathrm{~min}$. A solution of $\mathrm{HAuCl}_{4}(0.236 \mathrm{~mol} / \mathrm{L}$; $\mathrm{HAuCl}_{4} \cdot 3 \mathrm{H}_{2} \mathrm{O}$, 99.9+\%, Sigma-Aldrich; dissolved in water at room temperature) was then added into the mixture with stirring. The volume was adjusted with Nanopure water to make 5 $\mathrm{mL}$ total. The final powder suspension was kept stirring in the dark at room temperature for $6 \mathrm{~h}$ before drying in a $90^{\circ} \mathrm{C}$ oven for $16 \mathrm{~h}$.

The dried catalyst powder was divided into four samples, and each sample was treated with one of the procedures shown in Scheme 1; that is: (1) calcination in flowing air at $400^{\circ} \mathrm{C}$ for 3 $\mathrm{h}$ and cooling to room temperature in flowing air (Dried/Air),

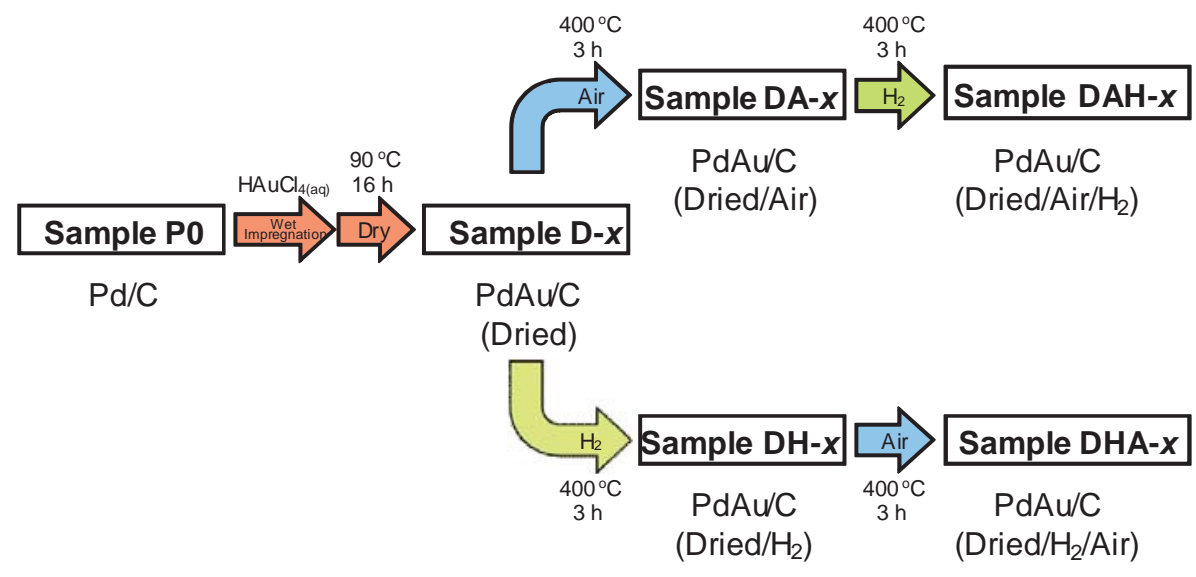

Scheme 1. Preparation routes of $\mathrm{PdAu} / \mathrm{C}$ samples. 
(2) calcination in flowing air at $400{ }^{\circ} \mathrm{C}$ for $3 \mathrm{~h}$ and cooling to room temperature in flowing air, then reduction in flowing hydrogen gas at $400{ }^{\circ} \mathrm{C}$ for $3 \mathrm{~h}$ and cooling to room temperature in flowing hydrogen gas (Dried/Air/ $\mathrm{H}_{2}$ ), (3) reduction in flowing hydrogen gas at $400{ }^{\circ} \mathrm{C}$ for $3 \mathrm{~h}$ and cooling to room temperature in flowing hydrogen gas (Dried/ $\mathrm{H}_{2}$ ), and (4) reduction in flowing hydrogen gas at $400{ }^{\circ} \mathrm{C}$ for $3 \mathrm{~h}$ and cooling to room temperature in flowing hydrogen gas, then calcination in flowing air at $400{ }^{\circ} \mathrm{C}$ for $3 \mathrm{~h}$ and cooling to room temperature in flowing air (Dried/ $\mathrm{H}_{2} /$ Air). These samples are designated as D- $x$, DA- $x$, DAH- $x$, DH- $x$, and DHA- $x$, respectively, where $x$ reflects the weight percent of Au. Prepared samples were stored in air, in the dark at room temperature.

\subsection{Catalyst characterization}

\subsubsection{ICP}

Elemental analysis of catalysts was conducted with a PerkinElmer inductively coupled plasma optical emission spectrometer (ICP-OES) Optima 4300 DV. Catalyst powder was mixed with aqua regia containing $10 \mathrm{~mL} \mathrm{HCl}_{\text {(aq) }}(1 \mathrm{~mol} / \mathrm{L}$, Fisher), and $0.3 \mathrm{~mL} \mathrm{HNO}_{3 \text { (aq) }}\left(70 \mathrm{wt} \%\right.$, Fisher); then heated at $90{ }^{\circ} \mathrm{C}$ for 30 min. After cooling down to room temperature, the solution was treated with a $0.45-\mu \mathrm{m}$ filter before ICP analysis of Pd and Au loadings.

\subsubsection{TEM}

Particle size and morphology of catalysts were characterized with a JEOL 2100 TEM. Catalyst powder was dispersed in isopropanol with ultrasonication, then deposited on a 200-mesh carbon/formvar TEM grid, and air-dried at room temperature.

\subsubsection{XAS}

XAS measurements were performed on the insertion-device beamline 10-ID-B of the Materials Research Collaborative Access Team (MRCAT) at the Advanced Photon Source at Argonne National Laboratory. The presence of harmonics was minimized with a cryogenically cooled double-crystal Si (111) monochromator in conjunction with an uncoated glass mirror. The monochromator was scanned continuously during the measurements with data points integrated over $0.5 \mathrm{eV}$ for 0.07 $\mathrm{s}$ per data point. Measurements were made in transmission mode with the ionization chambers optimized for the maximum current with linear response $\left(\sim 10^{10}\right.$ photons detected per sec) using a mixture of nitrogen and helium in the incident X-ray detector and a mixture of $\sim 20 \%$ argon in nitrogen in the transmission X-ray detector. Absorption was measured at both $\mathrm{Pd}$ and Au edges; a Pd or Au foil spectrum was acquired simultaneously with each measurement for calibration. Samples of catalyst powder were pressed into a cylindrical holder with a thickness chosen to give a total absorbance $(\mu x)$ at the Pd K (24.350 keV) and Au L LII (11.918 keV) edges of ca. 2.0, and an edge step $(\Delta \mu x)$ of ca. 0.5 . The sample holder was placed in a reactor cell (glass tube, length $18 \mathrm{in}$., diameter $0.75 \mathrm{in}$.) fitted at both ends with polyimide windows and stainless steel valves to isolate the reactor from the atmosphere. The reactor was purged with flowing hydrogen gas for 10 min and then sealed, in order to mimic the hydrogen atmosphere during HDC reactions. All spectra were measured at room temperature.

Experimental phase shifts and back-scattering amplitudes were obtained from reference compounds: Pd foil for Pd-Pd bonding, $\mathrm{Pd}\left(\mathrm{NH}_{3}\right)_{4}\left(\mathrm{NO}_{3}\right)_{2}$ (Aldrich) for Pd-O bonding, and $\mathrm{Au}$ foil for $\mathrm{Au}-\mathrm{Au}$ bonding. Experimental data of $\mathrm{Pd}$ and $\mathrm{Au}$ foil were used to determine the best fit of Debye-Waller factors (DWF) and amplitude reduction factors $\left(S_{0}\right)$ for phase shifts and back-scattering amplitudes in the FEFF fitting [51]. Along with the bond distances for Pd and Au foil, these values were used for determining the Pd-Au and Au-Pd FEFF phase shifts and back-scattering amplitudes. Standard procedures based on the WINXAS97 software [51] were used to extract the data [52]. The coordination parameters were obtained by a least-square fit in $k$ - and $R$-space of the nearest-neighbor, $k^{2}$-weighted Fourier transform (FT) data ( $k$ : photoelectron wave number, $R$ : bond distance). The data fitted equally well with both $k^{1}$ and $k^{3}$ weightings.

\subsection{Catalyst testing}

Aqueous-phase hydrodechlorination (HDC) of trichloroethene (TCE) at room temperature was chosen as the model reaction for catalytic testing. Batch reactions were performed similar to previous studies $[4,26,53]$. A screw-cap bottle $(250$ $\mathrm{mL}$, Alltech), containing $165 \mathrm{~mL}$ Nanopure water, $3 \mathrm{~mL} \mathrm{Na-}$ $\mathrm{HCO}_{3(\text { aq) }}$ buffer (0.08 mol/L; $\mathrm{NaHCO}_{3}, 99 \%$, Fisher), and a magnetic stir bar were sealed with PTFE-sealed threads and a PTFE-silicone septum. Hydrogen gas was bubbled into the bottle for 15 min to displace dissolved oxygen and to fill the headspace with a hydrogen atmosphere (1 atm). Then, $7 \mu \mathrm{L}$ TCE (99.5\%, Sigma-Aldrich) and $0.2 \mu \mathrm{L}$ pentane (99.7\%, Burdick and Jackson) internal standard, were injected into the sealed bottle. The overall solution was stirred for at least $3 \mathrm{~h}$ to reach equilibrium. In a separate vial, $\sim 50 \mathrm{mg}$ catalyst powder was dispersed in a mixture of $4.5 \mathrm{~mL}$ Nanopure water and $0.5 \mathrm{~mL}$ isopropanol with ultrasonication for $1 \mathrm{~min}$. At time $t=0$, the catalyst suspension was injected into the bottle. The reactor was magnetically stirred at $600 \mathrm{r} / \mathrm{min}$. The initial TCE concentration in liquid phase was $50.9 \mathrm{ppm}$, far below the saturation concentration of $1200 \mathrm{ppm}$ in water at $25^{\circ} \mathrm{C}$ [54]. The reaction was monitored through headspace gas chromatography (GC) using an Agilent Technologies 6890N GC with a flame ionization detector (FID) and a 60/80 Carbopack B/1\% SP-1000 packed column (Supelco 12487, Sigma-Aldrich). Reaction rates were determined from changes of TCE concentrations in the headspace. All reactions were performed at room temperature.

\section{Results and discussion}

\subsection{Elemental analysis and particle morphology}

ICP results of $\mathrm{Pd}$ and Au loadings are listed in Table 1. Pd loadings remained the same $(\sim 1 \mathrm{wt} \%)$ for all the samples, compared to the control Sample P0 ( $1 \mathrm{wt} \% \mathrm{Pd} / \mathrm{C})$. Au loadings, $0.1,0.4,1.1$, and $1.7 \mathrm{wt} \%$, matched the amount of Au added to 
Table 1

Catalyst compositions (as determined by ICP, treatments, and reaction rates, rate constant $k_{\text {cat }}$ and initial turnover frequency (TOF) determined from aqueous-phase TCE HDC with initial $C_{\mathrm{TCE}(\mathrm{aq})}=50.9 \mathrm{ppm}$ at room temperature $22 \pm 2{ }^{\circ} \mathrm{C}$ ).

\begin{tabular}{|c|c|c|c|c|c|c|}
\hline No. & Catalyst & $\begin{array}{l}\text { Pd weight loading } \\
\text { (wt\%) }\end{array}$ & $\begin{array}{c}\text { Au weight } \\
\text { loading (wt } \%)\end{array}$ & Treatment & $\begin{array}{c}\text { Rate constant } k_{\text {cat }}(\mathrm{L} \\
\left.\mathrm{g}_{\mathrm{Pd}}^{-1} \mathrm{~min}^{-1}\right)\end{array}$ & $\begin{array}{l}\text { Initial TOF }\left(10^{-3}\right. \\
\text { mol }_{\text {TCE }} \text { mol }_{\left.\mathrm{Pd}^{-1} \mathrm{~s}^{-1}\right)}\end{array}$ \\
\hline D-0.1 & $\mathrm{PdAu} / \mathrm{C}$ & 1.0 & 0.1 & Dried & 29 & 20 \\
\hline D- 0.4 & $\mathrm{PdAu} / \mathrm{C}$ & 1.0 & 0.4 & Dried & 85 & 58 \\
\hline D-1.1 & $\mathrm{PdAu} / \mathrm{C}$ & 1.0 & 1.1 & Dried & 89 & 61 \\
\hline D-1.7 & $\mathrm{PdAu} / \mathrm{C}$ & 1.0 & 1.7 & Dried & 33 & 22 \\
\hline DA-0.1 & $\mathrm{PdAu} / \mathrm{C}$ & 1.0 & 0.1 & Dried/air & 39 & 27 \\
\hline DA-0.4 & $\mathrm{PdAu} / \mathrm{C}$ & 1.0 & 0.4 & Dried/air & 130 & 88 \\
\hline DA-1.1 & $\mathrm{PdAu} / \mathrm{C}$ & 1.0 & 1.1 & Dried/air & 110 & 75 \\
\hline DA-1.7 & $\mathrm{PdAu} / \mathrm{C}$ & 1.0 & 1.7 & Dried/air & 22 & 15 \\
\hline DAH-0.1 & $\mathrm{PdAu} / \mathrm{C}$ & 1.0 & 0.1 & Dried/air/ $\mathrm{H}_{2}$ & 84 & 58 \\
\hline DAH-0.4 & $\mathrm{PdAu} / \mathrm{C}$ & 1.0 & 0.4 & Dried/air/ $\mathrm{H}_{2}$ & 310 & 210 \\
\hline DAH-1.1 & $\mathrm{PdAu} / \mathrm{C}$ & 1.0 & 1.1 & Dried/air/ $\mathrm{H}_{2}$ & 490 & 340 \\
\hline DAH-1.7 & $\mathrm{PdAu} / \mathrm{C}$ & 1.0 & 1.7 & Dried/air/ $\mathrm{H}_{2}$ & 310 & 210 \\
\hline DH-0.1 & $\mathrm{PdAu} / \mathrm{C}$ & 1.0 & 0.1 & Dried/ $/ \mathrm{H}_{2}$ & 64 & 44 \\
\hline DH-0.4 & $\mathrm{PdAu} / \mathrm{C}$ & 1.0 & 0.4 & Dried/ $\mathrm{H}_{2}$ & 71 & 49 \\
\hline DH-1.1 & $\mathrm{PdAu} / \mathrm{C}$ & 1.0 & 1.1 & Dried/ $\mathrm{H}_{2}$ & 59 & 41 \\
\hline DH-1.4 & $\mathrm{PdAu} / \mathrm{C}$ & 1.0 & 1.7 & Dried/ $/ \mathrm{H}_{2}$ & 63 & 43 \\
\hline DHA-0.1 & $\mathrm{PdAu} / \mathrm{C}$ & 1.0 & 0.1 & Dried/H $/ \mathrm{H}_{2} /$ air & 46 & 32 \\
\hline DHA-0.4 & $\mathrm{PdAu} / \mathrm{C}$ & 1.0 & 0.4 & Dried/H2/air & 71 & 49 \\
\hline DHA-1.1 & $\mathrm{PdAu} / \mathrm{C}$ & 1.0 & 1.1 & Dried/H $\mathrm{H}_{2} /$ air & 120 & 82 \\
\hline DHA-1.7 & $\mathrm{PdAu} / \mathrm{C}$ & 1.0 & 1.7 & Dried $/ \mathrm{H}_{2} /$ air & 210 & 140 \\
\hline P0 & $\mathrm{Pd} / \mathrm{C}$ & 1.0 & 0 & (Pretreatments only, control sample) & 32 & 22 \\
\hline
\end{tabular}

the different sets of catalysts.

Fig. 1 shows representative TEM images of PdAu/C samples, indicating that metal particles have roughly spherical morphology and a broad size distribution from $\sim 5 \mathrm{~nm}$ (Fig. 1(a)) to over $50 \mathrm{~nm}$ (Fig. 1(b)). Particle size analysis showed a bimodal size distribution for metal particles on $\mathrm{PdAu} / \mathrm{C}$ samples, with smaller particles around 5-10 nm (Fig. 1(a)) and larger particles around $30-100 \mathrm{~nm}$ (Fig. 1(b)). This is in contrast to the monometallic $1 \mathrm{wt} \% \mathrm{Pd} / \mathrm{C}$ catalyst, which has a relatively uniform size distribution of $3.5 \mathrm{~nm}$ Pd particles [55].

\subsection{Catalytic activity for TCE HDC reaction}

Reaction rates of TCE HDC were quantified using the rate constant $k_{\text {cat }}$ and initial turnover frequency (TOF, number of reacted TCE molecules per Pd atom per time), with the implicit assumption of first-order dependence in TCE and zero-order in $\mathrm{H}_{2}[26,27,57,58]$. $k_{\text {cat }}$ is the Pd-normalized reaction rate con-

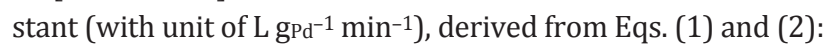
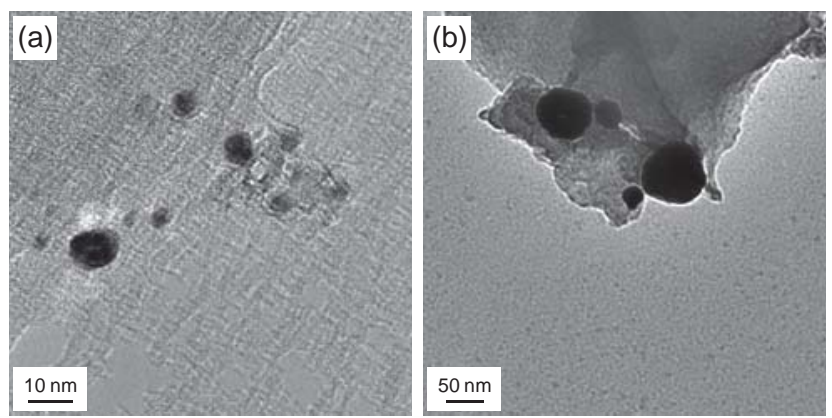

Fig. 1. Representative TEM images of sample DAH-1.1 with smaller particles around 5-10 nm (a) and larger particles around 30-100 nm (b).

$$
\begin{gathered}
\text { reaction rate }=\frac{-\mathrm{d} C_{\mathrm{TCE}}}{\mathrm{d} t}=k_{\text {meas }} C_{\mathrm{TCE}} \\
k_{\text {meas }}=k_{\text {cat }} C_{\text {cat }}
\end{gathered}
$$

where $k_{\text {meas }}$ is the measured first-order rate constant, and $C_{\mathrm{TCE}}$ and $C_{\text {cat }}$ are the concentrations of TCE and Pd in the liquid phase in the reactor, respectively. Dilute $\mathrm{NaHCO}_{3 \text { (aq) }}(\sim 1.4$ $\mathrm{mmol} / \mathrm{L}$ in the reactor) was chosen as the buffer, and $\mathrm{pH}$ was controlled between 8.3-6.0 for all the tests in order to minimize possible effects from salts and $\mathrm{pH}[58,59]$. All reactions reached $>90 \%$ TCE conversion and showed $>90 \%$ product selectivity to ethane as previously reported [26].

Results of catalyst activities are listed in Table 1; data points of initial TOF's at different compositions and treatments are plotted in Fig. 2. Most of the bimetallic $\mathrm{PdAu} / \mathrm{C}$ samples showed higher activities than the monometallic Pd/C (Sample P0), indicating that catalytic enhancement could be achieved by the addition of the Au precursor salt. Sample DAH-1.1 (initial TOF =

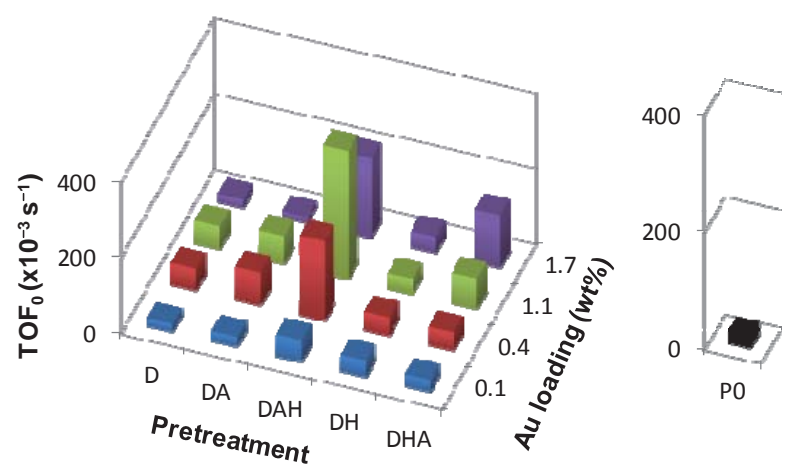

Fig. 2. TCE HDC reaction activity profiles of $\mathrm{PdAu} / \mathrm{C}$ catalysts with different $\mathrm{Au}$ loadings and treatment processes and $\mathrm{Pd} / \mathrm{C}$ control. 
$340 \times 10^{-3}$ mol $_{\text {TCE }}$ molpd $^{-1} \mathrm{~s}^{-1}$ ) was the most active, with an initial TOF value $>15$ times higher than $\mathrm{Pd} / \mathrm{C}$ (initial TOF $=22 \times$ $10^{-3}$ molTCE molpd $^{-1} \mathrm{~s}^{-1}$ ).

\subsection{Local atomic information from XAS measurements}

XAS is a powerful technique to acquire detailed structural and electronic information at an atomic level for monometallic NPs [60-62] and bimetallic NPs [4,16-22]. The EXAFS region provides local structural information including the types of neighboring atoms, coordination number $(N)$, and bond distance $(R)$. The results of the EXAFS fitting are shown in Table 2.

\subsection{Effect of Au loading on catalytic activity}

From the Pd edge, coordination numbers of bimetallic Pd-Au bonding $\left(N_{\mathrm{Pd}-\mathrm{Au}}\right)$ generally increased with higher $\mathrm{Au}$ loadings (Table 2). NPd-Au was as high as $7.0-7.5$ which was $60 \%-70 \%$ of total coordination number of $\mathrm{Pd}\left(N_{\mathrm{Pd}}\right)$. Fourier transform (FT) fits from the EXAFS data also exhibited a dependence on bimetallic interaction with Au loadings for the same Dried/Air $/ \mathrm{H}_{2}$ treatments (Fig. 3). FT fits of sample DAH-0.1 (Au 0.1 wt\%) were almost the same as Pd foil (Fig. 3(a)), implying little to no Pd-Au interaction. Sample DAH-0.4 (Au $0.4 \mathrm{wt} \%$ ) showed a change in the ratio of the two characteristic Pd peaks (the two highest FT magnitude peaks) and small shifts in the node positions of the FT imaginary parts (Fig. 3(b)) due to interference from the Pd-Pd and Pd-Au contributions, indicating bimetallic Pd-Au bonding. Sample DAH-1.1 (Au $1.1 \mathrm{wt} \%$ ) and DAH-1.7 (Au $1.7 \mathrm{wt} \%$ ) each showed nearly equal ratios of the two characteristic Pd peaks (Fig. 3(c) and (d)), indicating more Pd-Au interaction.

From the Au edge, Au-Pd interaction was not apparent for the majority of $\mathrm{PdAu} / \mathrm{C}$ samples (Table 2), with the exceptions of DAH-0.1, DA-0.4, DAH-0.4, and DAH-1.1 with small $N_{\text {Au-Pd }}$ values $\left(N_{\mathrm{Au}-\mathrm{Pd}}=1.7 \%-2.6 \%, 14 \%-22 \%\right.$ of total coordination number of $\mathrm{Au}$ ). This is indicative that for almost all of the catalysts, the majority of $\mathrm{Au}$ atoms were present as monometallic $\mathrm{Au}$, as opposed to being in a bimetallic PdAu structure. Conversely, the number of Pd atoms in the bimetallic structure increased with increasing $\mathrm{Au}$ loadings. For example, Fig. 4 shows FT results from the EXAFS data of samples with different $\mathrm{Au}$ loadings under the same Dried/Air $/ \mathrm{H}_{2}$ treatments. Compared to $\mathrm{Au}$ foil, samples with lower Au loadings (DAH-0.1, DAH-0.4, and DAH-1.1) exhibited noticeable differences in shape and relative peak magnitudes and node positions of the imaginary parts (Fig. 4(a)-(c)) due to the Au-Pd interaction.

Sample DAH-1.7, which had the highest Au loading, appeared similar to Au foil (Fig. 4(d)), indicative of insignificant Au-Pd interaction. The small shift in the $R_{\mathrm{Au}-\mathrm{Au}}$ between DAH-1.7 (2.86 ̊) and Au foil (2.88 ̊), could possibly be due to the smaller particle size of the $\mathrm{Au}$ in DAH-1.7. With increasing $\mathrm{Au}$ loadings, the additional $\mathrm{Au}$ atoms formed monometallic $\mathrm{Au}$ particles, diluting the Au-Pd interaction. Indeed, the Dried/Air/H2 process enhanced the bimetallic Au-Pd interac- tion (see Sec. 3.5) while other processes led to no or little $\mathrm{Au}-\mathrm{Pd}$

Table 2

EXAFS fit parameters.

\begin{tabular}{|c|c|c|c|c|c|}
\hline No. & Catalyst & Edge & $\begin{array}{c}\text { Scattering } \\
\text { path }\end{array}$ & $\begin{array}{c}N \\
( \pm 10 \%)\end{array}$ & $\begin{array}{c}R(\AA ̊) \\
( \pm 0.02 \AA)\end{array}$ \\
\hline \multirow[t]{2}{*}{ D-0.1 } & $\mathrm{PdAu} / \mathrm{C}$ & $\mathrm{Pd}$ & Pd-Pd & 9.7 & 2.75 \\
\hline & & $\mathrm{Au}$ & $\mathrm{Au}-\mathrm{Au}$ & 10.8 & 2.87 \\
\hline \multirow{2}{*}{ DA-0.1 } & $\mathrm{PdAu} / \mathrm{C}$ & $\mathrm{Pd}$ & Pd-Pd & 10.0 & 2.74 \\
\hline & & $\mathrm{Au}$ & $\mathrm{Au}-\mathrm{Au}$ & 10.3 & 2.84 \\
\hline \multirow{3}{*}{ DAH-0.1 } & $\mathrm{PdAu} / \mathrm{C}$ & $\mathrm{Pd}$ & Pd-Pd & 11.1 & 2.75 \\
\hline & & $\mathrm{Au}$ & $\mathrm{Au}-\mathrm{Au}$ & 10.1 & 2.87 \\
\hline & & & $\mathrm{Au}-\mathrm{Pd}$ & 2.0 & 2.79 \\
\hline \multirow[t]{2}{*}{ DH-0.1 } & $\mathrm{PdAu} / \mathrm{C}$ & $\mathrm{Pd}$ & Pd-Pd & 9.8 & 2.79 \\
\hline & & $\mathrm{Au}$ & $\mathrm{Au}-\mathrm{Au}$ & 9.4 & 2.83 \\
\hline \multirow[t]{2}{*}{ DHA-0.1 } & $\mathrm{PdAu} / \mathrm{C}$ & $\mathrm{Pd}$ & Pd-Pd & 10.2 & 2.75 \\
\hline & & $\mathrm{Au}$ & $\mathrm{Au}-\mathrm{Au}$ & 9.4 & 2.84 \\
\hline \multirow[t]{2}{*}{ D-0.4 } & $\mathrm{PdAu} / \mathrm{C}$ & $\mathrm{Pd}$ & $\mathrm{Pd}-\mathrm{Pd}$ & 9.2 & 2.75 \\
\hline & & $\mathrm{Au}$ & $\mathrm{Au}-\mathrm{Au}$ & 11.0 & 2.86 \\
\hline \multirow[t]{4}{*}{ DA-0.4 } & $\mathrm{PdAu} / \mathrm{C}$ & $\mathrm{Pd}$ & Pd-Pd & 6.1 & 2.75 \\
\hline & & & $\mathrm{Pd}-\mathrm{Au}$ & 5.3 & 2.79 \\
\hline & & $\mathrm{Au}$ & $\mathrm{Au}-\mathrm{Au}$ & 9.1 & 2.86 \\
\hline & & & $\mathrm{Au}-\mathrm{Pd}$ & 2.6 & 2.80 \\
\hline \multirow[t]{4}{*}{ DAH-0.4 } & $\mathrm{PdAu} / \mathrm{C}$ & $\mathrm{Pd}$ & Pd-Pd & 6.4 & 2.75 \\
\hline & & & $\mathrm{Pd}-\mathrm{Au}$ & 5.5 & 2.80 \\
\hline & & $\mathrm{Au}$ & $\mathrm{Au}-\mathrm{Au}$ & 9.7 & 2.84 \\
\hline & & & $\mathrm{Au}-\mathrm{Pd}$ & 2.2 & 2.79 \\
\hline \multirow[t]{3}{*}{ DH-0.4 } & $\mathrm{PdAu} / \mathrm{C}$ & $\mathrm{Pd}$ & Pd-Pd & 6.6 & 2.76 \\
\hline & & & $\mathrm{Pd}-\mathrm{Au}$ & 5.2 & 2.79 \\
\hline & & $\mathrm{Au}$ & $\mathrm{Au}-\mathrm{Au}$ & 10.9 & 2.85 \\
\hline \multirow[t]{2}{*}{ DHA-0.4 } & $\mathrm{PdAu} / \mathrm{C}$ & $\mathrm{Pd}$ & Pd-Pd & 9.0 & 2.75 \\
\hline & & $\mathrm{Au}$ & $\mathrm{Au}-\mathrm{Au}$ & 10.8 & 2.86 \\
\hline \multirow[t]{2}{*}{ D-1.1 } & $\mathrm{PdAu} / \mathrm{C}$ & $\mathrm{Pd}$ & $\mathrm{Pd}-\mathrm{Cl}$ & 3.8 & 2.33 \\
\hline & & $\mathrm{Au}$ & $\mathrm{Au}-\mathrm{Au}$ & 10.7 & 2.86 \\
\hline \multirow[t]{3}{*}{ DA-1.1 } & $\mathrm{PdAu} / \mathrm{C}$ & $\mathrm{Pd}$ & Pd-Pd & 3.5 & 2.75 \\
\hline & & & $\mathrm{Pd}-\mathrm{Au}$ & 7.0 & 2.79 \\
\hline & & $\mathrm{Au}$ & $\mathrm{Au}-\mathrm{Au}$ & 10.3 & 2.83 \\
\hline \multirow[t]{4}{*}{ DAH-1.1 } & $\mathrm{PdAu} / \mathrm{C}$ & $\mathrm{Pd}$ & Pd-Pd & 4.8 & 2.75 \\
\hline & & & $\mathrm{Pd}-\mathrm{Au}$ & 6.4 & 2.79 \\
\hline & & $\mathrm{Au}$ & $\mathrm{Au}-\mathrm{Au}$ & 10.3 & 2.86 \\
\hline & & & $\mathrm{Au}-\mathrm{Pd}$ & 1.7 & 2.79 \\
\hline \multirow[t]{3}{*}{ DH-1.1 } & $\mathrm{PdAu} / \mathrm{C}$ & $\mathrm{Pd}$ & Pd-Pd & 4.4 & 2.75 \\
\hline & & & $\mathrm{Pd}-\mathrm{Au}$ & 7.0 & 2.79 \\
\hline & & $\mathrm{Au}$ & $\mathrm{Au}-\mathrm{Au}$ & 11.0 & 2.86 \\
\hline \multirow{3}{*}{ DHA-1.1 } & $\mathrm{PdAu} / \mathrm{C}$ & $\mathrm{Pd}$ & Pd-Pd & 4.4 & 2.75 \\
\hline & & & $\mathrm{Pd}-\mathrm{Au}$ & 7.0 & 2.79 \\
\hline & & $\mathrm{Au}$ & $\mathrm{Au}-\mathrm{Au}$ & 10.9 & 2.84 \\
\hline \multirow[t]{3}{*}{ D-1.7 } & $\mathrm{PdAu} / \mathrm{C}$ & $\mathrm{Pd}$ & $\mathrm{Pd}-\mathrm{Cl}$ & 4.0 & 2.33 \\
\hline & & $\mathrm{Au}$ & $\mathrm{Au}-\mathrm{Au}$ & 9.5 & 2.86 \\
\hline & & & $\mathrm{Au}-\mathrm{Cl}$ & 0.8 & 2.29 \\
\hline DA-1.7 & $\mathrm{PdAu} / \mathrm{C}$ & $\mathrm{Pd}$ & Pd-Pd & 2.1 & 2.75 \\
\hline & & & $\mathrm{Pd}-\mathrm{Au}$ & 5.7 & 2.80 \\
\hline & & & Pd-O & 1.3 & 2.04 \\
\hline & & $\mathrm{Au}$ & $\mathrm{Au}-\mathrm{Au}$ & 11.1 & 2.86 \\
\hline DAH-1.7 & $\mathrm{PdAu} / \mathrm{C}$ & $\mathrm{Pd}$ & Pd-Pd & 4.5 & 2.75 \\
\hline & & & $\mathrm{Pd}-\mathrm{Au}$ & 6.5 & 2.79 \\
\hline & & $\mathrm{Au}$ & $\mathrm{Au}-\mathrm{Au}$ & 11.0 & 2.86 \\
\hline DH-1.7 & $\mathrm{PdAu} / \mathrm{C}$ & $\mathrm{Pd}$ & Pd-Pd & 4.3 & 2.74 \\
\hline & & & $\mathrm{Pd}-\mathrm{Au}$ & 7.5 & 2.79 \\
\hline & & $\mathrm{Au}$ & $\mathrm{Au}-\mathrm{Au}$ & 11.0 & 2.86 \\
\hline DHA-1.7 & $\mathrm{PdAu} / \mathrm{C}$ & $\mathrm{Pd}$ & $\mathrm{Pd}-\mathrm{Pd}$ & 2.9 & 2.75 \\
\hline & & & $\mathrm{Pd}-\mathrm{Au}$ & 5.4 & 2.80 \\
\hline & & & Pd-O & 0.9 & 2.04 \\
\hline & & $\mathrm{Au}$ & $\mathrm{Au}-\mathrm{Au}$ & 10.9 & 2.85 \\
\hline P0 & $\mathrm{Pd} / \mathrm{C}$ & $\mathrm{Pd}$ & Pd-Pd & 10.5 & 2.80 \\
\hline
\end{tabular}

$N$ : coordination number, $R$ : bond distance, RT: room temperature. 

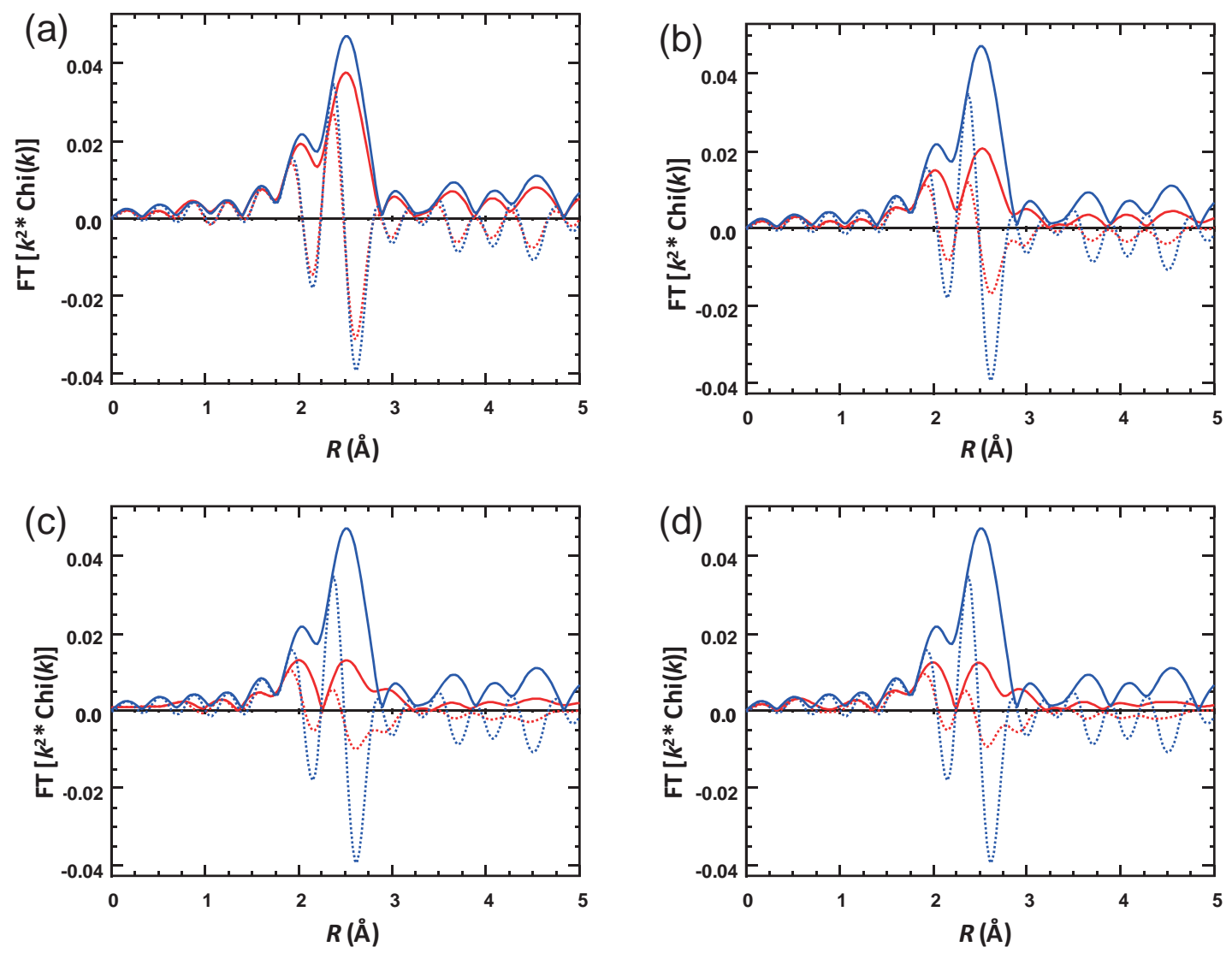

Fig. 3. Fourier transform ( $k^{2}$ weighted, $\Delta k=2.7-11.8 \AA^{-1}$; solid line: magnitude, dotted line: imaginary components) of Pd K edge EXAFS data for Pd foil (blue) and PdAu/C samples (red). (a) DAH-0.1; (b) DAH-0.4; (c) DAH-1.1; (d) DAH-1.7.
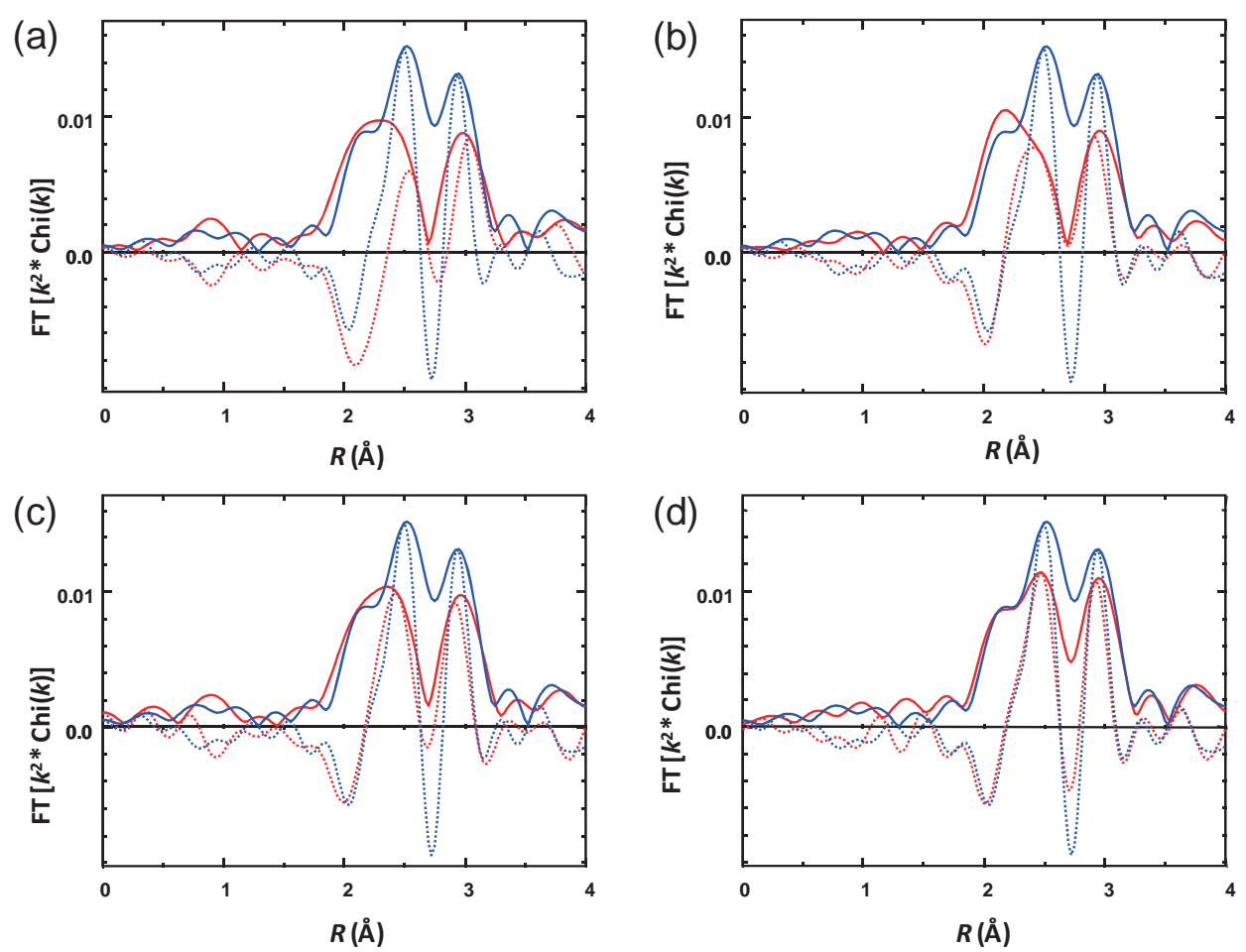

Fig. 4. Fourier transform ( $k^{2}$ weighted; solid line: magnitude, dotted line: imaginary components) of Au L III edge EXAFS data for Au foil (blue) and $\mathrm{PdAu} / \mathrm{C}$ samples (red). (a) Sample DAH-0.1 $\left(\Delta k=2.7-11.8 \AA^{-1}\right)$; (b) Sample DAH-0.4 ( $\left.\Delta k=2.6-11.7 \AA^{-1}\right)$; (c) Sample DAH-1.1 $\left(\Delta k=2.6-11.5 \AA^{-1}\right)$; (d) Sample DAH-1.7 $\left(\Delta k=2.6-12.0 \AA^{-1}\right)$. 
interaction even at low Au loadings. This implies that most of the $\mathrm{Pd}-\mathrm{Au}$ interaction was in smaller particles, while larger particles were mostly monometallic $\mathrm{Au}$, in accordance with the observed bimodal size distribution from TEM. This interpretation is consistent with the work by Hutchings and co-workers [50], who synthesized supported PdAu catalysts by co-impregnation also resulting in bimodal size distribution with $\mathrm{Au}$ forming large clusters.

Significantly (Table 2), Au stabilized metallic Pd under high-temperature calcination. Based on our previous studies[4], Pd/C was fully oxidized after calcination in flowing air at $400{ }^{\circ} \mathrm{C}$, could not be reduced in $\mathrm{H}_{2}$ at room temperature, and showed no activity for TCE HDC. However, addition of $\mathrm{Au}$, as low as $0.1 \mathrm{wt} \%$, significantly improved Pd oxidization resistance. Samples DA-0.1 DHA-0.1, DA-0.4, DHA-0.4, DA-1.1, and DHA-1.1 exhibited no detectable oxidized Pd, and also had enhanced catalytic activities (Table 1 and 2). This stabilization effect was also found in our previous investigation of colloidal Pd-on-Au NPs [4]. Curiously, the air-treated samples with the highest Au loading, DA-1.7 and DHA-1.7, did have partial Pd oxidation ( $33 \%$ for DA-1.7, $\sim 23 \%$ for DHA-1.7; percentages calculated from the ratio between $N_{\text {Pd-0 }}$ of the sample and $N_{\text {Pd-0 }}$ $(=4)$ of fully oxidized PdO). We speculate that this may be due to the $\mathrm{Cl}^{-}$ions from the gold salt; $\mathrm{Cl}^{-}$ions can be oxidatively adsorbed to Pd under acidic conditions and reduce Pd activity $[53,63]$. Indeed, adding the Au precursor to these samples also added $0.73 \mathrm{mmol} \mathrm{Cl}$ resulting in a $\mathrm{Cl}: \mathrm{Pd}$ atomic ratio of 3.9:1.

The Au-Au bond distances of all $\mathrm{PdAu} / \mathrm{C}$ samples were similar (2.83-2.87 ̊) and slightly less than Au foil (2.88 ̊̊), which is typical for NPs. The Pd-Pd bond distance of Pd/C (2.80 $\mathrm{A})$ was larger than Pd foil (2.75 ̊) and similar to Pd-H [64], which was expected since XAS measurements were conducted under hydrogen atmosphere. In general, the hydride disappeared with the addition of $\mathrm{Au}$, and the bimetallic $\mathrm{PdAu} / \mathrm{C}$ samples $\left(N_{\text {Pd-Pd }}=2.74-2.76 \AA\right.$ ) became similar to Pd foil with the exception of the sample with the lowest Au loading, DH-0.1 ( $N_{\mathrm{Pd}-\mathrm{Pd}}=$ $2.79 \AA$ ) , which was more like Pd-H due to its lack of bimetallic interaction.

Scheme 2 shows our proposed catalyst structures, summarizing the general effect of Au loadings and Fig. 5 shows profiles of reaction activities and bimetallic interaction (Pd-Au and

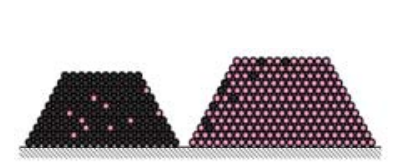

(a) Au 0.1 wt $\%$

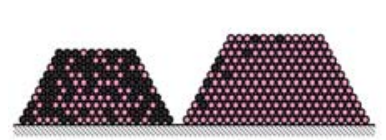

(c) Au $1.1 \mathrm{wt} \%$

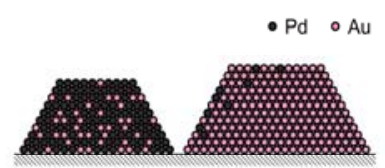

(b) Au 0.4 wt \%

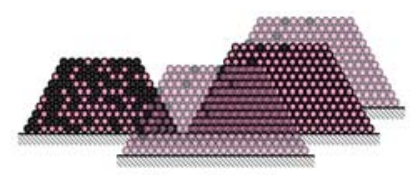

(d) Au $1.7 \mathrm{wt} \%$
Scheme 2. Illustration of proposed cross-section structures of $\mathrm{PdAu} / \mathrm{C}$ samples with different Au loadings. (a) $0.1 \mathrm{wt} \%$; (b) $0.4 \mathrm{wt} \%$; (c) $1.1 \mathrm{wt} \%$; (d) $1.7 \mathrm{wt} \%$.

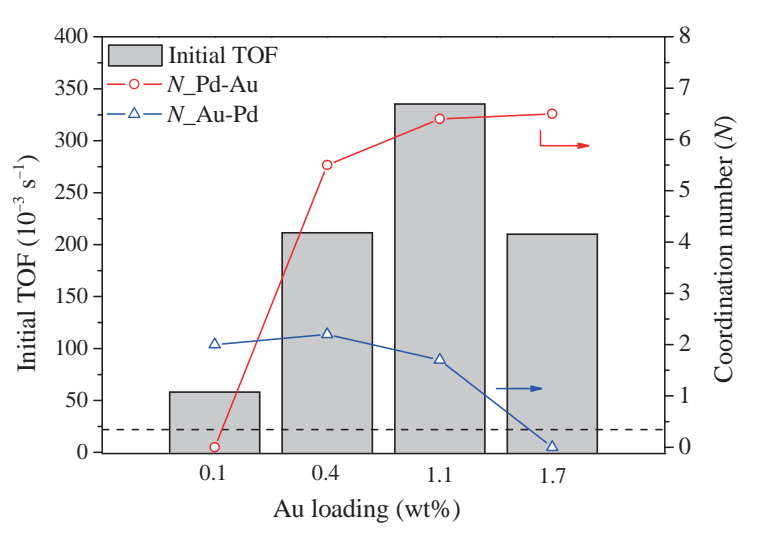

Fig. 5. Relationship between TCE HDC reaction activities and bimetallic interaction (Pd-Au and $\mathrm{Au}-\mathrm{Pd})$ at different $\mathrm{Au}$ loadings under the Dried/Air/H $/ \mathrm{H}_{2}$ process (dotted line: initial TOF $\left(22 \times 10^{-3}\right.$ mol $_{\mathrm{TCE}}$ mol$_{\mathrm{Pd}^{-1}}$ $\mathrm{s}^{-1}$ ) value of the control Sample P0 Pd/C).

$\mathrm{Au}-\mathrm{Pd}$ ) at different $\mathrm{Au}$ loadings under the same treatment process (dried/air/ $\mathrm{H}_{2}$, as an example). Higher $\mathrm{Au}$ loadings led to more $\mathrm{Pd}-\mathrm{Au}$ interaction (higher $N_{\mathrm{Pd}-\mathrm{Au}}$ ) but less $\mathrm{Au}-\mathrm{Pd}$ interaction (lower $\left.N_{\text {Au-Pd }}\right)$. Sample DAH-1.1 $\left(N_{\text {Pd-Au }}=6.4, N_{\text {Au-Pd }}=1.7\right)$ was the most active (initial TOF $=340 \times 10^{-3}$ mol $_{\mathrm{TCE}}$ mol $_{\mathrm{Pd}^{-1}}$ $\mathrm{s}^{-1}$ ). The dried/air $/ \mathrm{H}_{2}$ process provided the highest activities than other processes, and exhibited a volcano-shape curve for activities among different Au loadings. While initial TOFs increased with $\mathrm{Au}$ loadings for samples up to $1.1 \mathrm{wt} \% \mathrm{Au}$, higher loadings resulted in a decrease in activity. DAH-1.7 had an initial TOF $=210 \times 10^{-3}$ mol $_{\mathrm{TCE}}$ mol $_{\mathrm{Pd}^{-1}} \mathrm{~s}^{-1}$; a $50 \%$ decrease compared to DAH-1.1. An EXAFS comparison of DAH-1.1 and DAH-1.7 (Table 2 and Fig. 6) showed that DAH-1.1 and DAH-1.7 coordination numbers were similar from the Pd edge (DAH-1.1: $N_{\text {Pd-Pd }}=4.8, N_{\text {Pd-Au }}=6.4 ;$ DAH-1.7: $N_{\text {Pd-Pd }}=4.5, N_{\text {Pd-Au }}=6.5$ ), however, the higher loaded sample showed a higher $\mathrm{Au}-\mathrm{Au}$ interaction and almost no measurable $\mathrm{Au}-\mathrm{Pd}$ interaction from the Au edge (DAH-1.1: $N_{\mathrm{Au}-\mathrm{Au}}=10.3, N_{\mathrm{Au}-\mathrm{Pd}}=1.7$; DAH-1.7: $N_{\mathrm{Au}-\mathrm{Au}}=11.0, N_{\mathrm{Au}-\mathrm{Pd}}=0$ ). This suggests $\mathrm{Au}$ interacted with $\mathrm{Pd}$

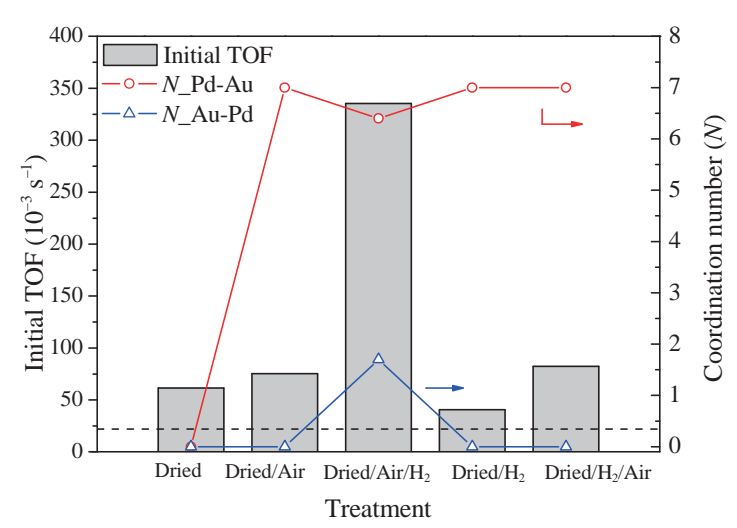

Fig. 6. Relationship between TCE HDC reaction activities and bimetallic interaction (Pd-Au and $\mathrm{Au}-\mathrm{Pd})$ with different treatment processes at the same $1.1 \mathrm{wt} \% \mathrm{Au}$ loading (dotted line: initial TOF value $\left(22 \times 10^{-3}\right.$ mol $_{\mathrm{TCE}} \mathrm{mol}_{\mathrm{Pd}^{-1}} \mathrm{~s}^{-1}$ ) of the control Sample P0 Pd/C). 
such that DAH-1.1 and DAH-1.7 were similar from the Pd edge; on the other hand, the excess Au in DAH-1.7 could have resulted in the formation of large Au clusters which possibly blocked the PdAu bimetallic particles, which is consistent with the lower catalytic activity and higher $N_{\mathrm{Au}-\mathrm{Au}}$ of DAH-1.7.

\subsection{Effect of treatment on catalytic activity}

As shown in Fig. 2, catalytic activities were influenced by different treatments, even at the same PdAu composition, and could be explained by changes in the bimetallic interaction as shown from EXAFS. Fig. 6 shows activity and coordination numbers as a function of treatment for the $1.1 \mathrm{wt} \% \mathrm{Au}$ samples. Samples with drying only (D-0.1, D-0.4, D-1.1, D-1.7) showed no bimetallic interaction since the temperature $\left(90^{\circ} \mathrm{C}\right)$ was low and no significant Pd-Au or Au-Pd bonding was observed (Table 2); the catalytic activities were only slightly promoted (D-0.4, D-1.1) or remained similar to Pd/C (D-0.1, D-1.7, Table 1). Au has a higher reduction potential than $\mathrm{Pd}$, and galvanic replacement of Pd by Au was expected. This can be seen in the EXAFS results, Pd-Cl (Table 2) was present for the higher loaded Au samples (D-1.1 and D-1.7). In addition, for the dried samples $\mathrm{Au}$ was in the $\mathrm{Au}-\mathrm{Au}$ form except for D-1.7. At this loading, the amount of electrons necessary to reduce all of the added $\mathrm{Au}^{3+}(0.516 \mathrm{mmol} \mathrm{e})$ was in excess of that available upon oxidizing $\mathrm{Pd}^{0}$ to $\mathrm{Pd}^{2+}\left(0.376 \mathrm{mmol} \mathrm{e}^{-}\right.$in $2 \mathrm{~g}$ of catalyst), resulting in incomplete reduction of the $\mathrm{Au}$ as exhibited by the existence of $\mathrm{Au}-\mathrm{Cl}$ bonding. The slightly higher activities for D-0.4 and D-1.1 were likely due to promotion from a small amount of $\mathrm{Au}^{0}$ atoms. At the extremes, the lowest loaded sample, D-0.1 may have had too few $\mathrm{Au}^{0}$ atoms for measurable promotion, while D-1.7 might have had excess $\mathrm{Cl}^{-}$ions so that Au promotion was not obvious.

Samples with the dried/air process (DA-0.1, DA-0.4, DA-1.1, DA-1.7) generally exhibited significant bimetallic interaction from both the $\mathrm{Pd}$ and $\mathrm{Au}$ edges (e.g. increased $\mathrm{Pd}-\mathrm{Au}$ and $\mathrm{Au}-\mathrm{Pd}$ ) and also showed the Au stabilization effect for Pd oxidization resistance. $\mathrm{Pd}$ and $\mathrm{Au}$ are thermodynamically miscible over their entire composition; thus, it is not unexpected to have more bimetallic interaction from alloying after high-temperature treatment. DA-0.1 did not have detectable $\mathrm{Pd}-\mathrm{Au}$ and Au-Pd probably due to its low Au loading. DA-1.1 and DA-1.7 had Pd-Au but no Au-Pd because most Au presented in the larger Au-rich particles, as mentioned in Sec. 3.4. As such, any $\mathrm{Au}-\mathrm{Pd}$ interaction was undetectable due to the high $\mathrm{Au}-\mathrm{Au}$ at high $\mathrm{Au}$ loadings. The Au stabilization effect, also mentioned in Sec. 3.4, led to no detectable Pd-O except for DA-1.7 with effects from initial excess $\mathrm{Cl}^{-}$ions. The catalytic activities were promoted for DA-0.4 and DA-1.1 most likely due to bimetallic interaction. DA-0.1, with the low Au loading, remained similar to Pd/C. DA-1.7 had a slightly lower activity than $\mathrm{Pd} / \mathrm{C}$ because of initial excess $\mathrm{Cl}^{-}$ions and resulting $\mathrm{Pd}-\mathrm{O}$ and lower Pd-Au.

Samples with the dried/air/H2 process (DAH-0.1, DAH-0.4, DAH-1.1, DAH-1.7) also had significant bimetallic interaction, with the exception of DAH-0.1, which had the lowest Au loading. DAH-0.4 and DAH-1.1 had both Pd-Au and Au-Pd interac- tions while no Au-Pd could be observed from DAH-1.7, likely due once again to the presence of larger Au-rich particles. Compared to the dried/air samples, where only DA-0.4 had measurable $\mathrm{Pd}-\mathrm{Au}$ and $\mathrm{Au}-\mathrm{Pd}$, the dried/air/ $\mathrm{H}_{2}$ process might be more amenable toward the alloying of $\mathrm{Pd}$ and $\mathrm{Au}$ atoms, as the high temperature $\mathrm{H}_{2}$ treatment seems to promote this. As expected, following the high temperature $\mathrm{H}_{2}$ treatment no oxidized Pd or Au was detected in the DAH samples. Compared to all the other treatment protocols, the catalytic activities of the dried/air/ $\mathrm{H}_{2}$ samples were generally higher across compositions.

Samples with the dried/H2 process (DH-0.1, DH-0.4, DH-1.1, DH-1.4) also showed Pd-Au bimetallic interaction except for the lowest loaded sample, DH-0.1. No Au-Pd bonding was detected in any of the samples. No oxidized Pd or Au was detected, as was expected under the high-temperature $\mathrm{H}_{2}$ treatment. The catalytic activities of the dried/air/ $\mathrm{H}_{2}$ samples were slightly promoted compared to $\mathrm{Pd} / \mathrm{C}$, but were similar regardless of Au loading.

Samples with the dried/ $\mathrm{H}_{2}$ /air process (DHA-0.1, DHA-0.4, DHA-1.1, DHA-1.7) showed bimetallic interaction with only $\mathrm{Pd}-\mathrm{Au}$ for DHA-1.1 and DHA-1.7. Like the dried/ $\mathrm{H}_{2}$ samples, no $\mathrm{Au}-\mathrm{Pd}$ bonding was detected, indicating that most $\mathrm{Au}$ atoms were still in large Au-rich particles and had little interaction with Pd atoms. DHA-1.7 had some Pd-O bonding, which may be due to excess $\mathrm{Cl}^{-}$ions preventing $\mathrm{Pd}$ atoms from contacting $\mathrm{Au}$ atoms, leading to less Pd oxidization resistance and similar EXAFS results as DA-1.7 synthesized with the dried/air process. However, different from DA-1.7 and other dried/air samples, the catalytic activities of the dried/ $\mathrm{H}_{2} /$ air samples increased with $\mathrm{Au}$ loadings, and DHA-1.7 was the most active one. The explanation for this difference is not understood. Fig. 6 and Scheme 3 illustrate these effects.

Several researchers observed that, for PdAu materials under high-temperature calcination in air, Pd tends to be in the shell of particles, and $\mathrm{Au}$ in the core, due to the lower reduction potential of Pd $[49,65]$. We speculate that the Au and Pd in the samples prepared with the air calcination process may migrate to form a Pd-rich shell and Au-rich core structure. On the other hand, samples synthesized with the $\mathrm{H}_{2}$ reduction process had little migration; since there was no air present, addition of $\mathrm{Au}$ should only lead to $\mathrm{Au}$ atoms deposited on the surface of $\mathrm{Pd}$

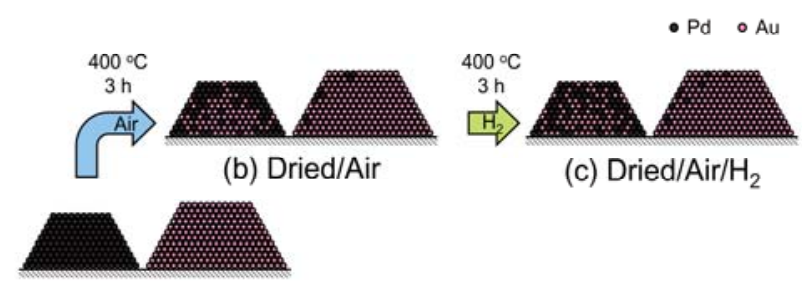

(a) Dried

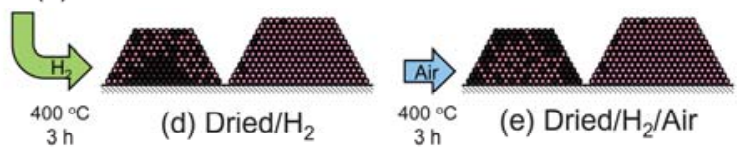

Scheme 3. Schematic illustration of proposed cross-section structures of PdAu/C samples with different treatments. (a) Dried; (b) Dried/Air; (c) Dried/Air/ $\mathrm{H}_{2}$; (d) Dried/H2; (e) Dried/H2/Air. 
particles.

To summarize, we hypothesize that the dried/air process led to a Pd-rich shell/Au-rich core structure due to atomic migration in air at high temperature (Scheme 3(a)), but led to little increase in activity. Addition of the $\mathrm{H}_{2}$ treatment step to the dried/air process (dried/air/H2 Scheme 3(b)) caused local alloying of the core-shell particles, resulting in better bimetallic interaction and the highest activities of all the different treatment methods. The dried $/ \mathrm{H}_{2}$ process resulted in only a small amount of $\mathrm{Au}$ atoms interacting with $\mathrm{Pd}$ atoms to form a possible Au-rich shell/Pd-rich core structure since no air was present during calcination; the activities were therefore only slightly promoted. The dried/H2/air process might increase surface Pd amount due to atomic migration in calcination; so the activities became higher than the dried/ $\mathrm{H}_{2}$ samples. As shown in Scheme 3, different treatments might lead to similar bimetallic interaction but also very different reaction activities, which could be explained by the above analysis.

\section{Conclusions}

Bimetallic supported PdAu catalysts, synthesized by adding gold salt to existing supported Pd catalysts, were investigated for the higher activities and corresponding nanostructures. Bimetallic $\mathrm{PdAu} / \mathrm{C}$ catalysts were successfully synthesized with well-established industrial processes of catalyst manufacture, including impregnation, drying. Catalyst composition and post-treatments revealed were both important to the resulting metal nanostructure. The most active $\mathrm{PdAu} / \mathrm{C}$ catalyst (Pd 1.0 $w t \%, \mathrm{Au} 1.1 \mathrm{wt} \%$, dried/air $/ \mathrm{H}_{2}$ process, initial TOF $=340 \times$
$10^{-3}$ molTcE $_{\text {Tol-1 }}^{-1} \mathrm{~s}^{-1}$ ) showed an activity $>15$ times higher than $\mathrm{Pd} / \mathrm{C}\left(\mathrm{Pd} 1.0 \mathrm{wt} \%\right.$, initial TOF $=22 \times 10^{-3} \mathrm{~mol}_{\mathrm{TCE}} \mathrm{mol}_{\mathrm{Pd}^{-1} \mathrm{~s}^{-1}}$ ) for aqueous-phase TCE HDC. TEM images indicated that PdAu/C catalysts might have a bimodal size distribution with smaller particles around 5-10 $\mathrm{nm}$ and larger particles around 30-100 nm. XAS results further suggested that larger particles may be $\mathrm{Au}$-rich, and bimetallic smaller. $\mathrm{Au}$ stabilized metallic $\mathrm{Pd}$ against oxidation under calcination up to $400{ }^{\circ} \mathrm{C}$; however, initial excess $\mathrm{Cl}^{-}$ions inhibited this stabilization effect. Nanostructure models were proposed for effects of Au loading and treatment, in accordance with EXAFS data and catalytic results, exhibiting the structure-activity relationships. Among all the treatments tested, the Dried/Air/ $\mathrm{H}_{2}$ process led to a probable Pd-rich shell/Au-rich core structure with higher bimetallic interaction and the most active catalytic performance.

\section{Acknowledgments}

This work is supported by the National Science Foundation, United States (EEC-0647452) and the Welch Foundation (C-1676). Materials Research Collaborative Access Team (MRCAT) operations (at the Advanced Photon Source, Argonne National Laboratory) are supported by the U. S. Department of Energy and the MRCAT member institutions. Use of the Advanced Photon Source is supported by the U. S. Department of Energy, Office of Science, and Office of Basic Energy Sciences (Contract\# DE-AC02-06CH11357). We thank Dr. Hitesh G. Bagaria (Rice University) for collecting TEM images, Prof. Mason B. Tomson (Rice University) for use of ICP-OES, Dr. Ping Zhang (Rice University) for assisting with ICP-OES operations.

\section{Graphical Abstract}

Chin. J. Catal., 2016, 37: 1776-1786 doi: 10.1016/S1872-2067(16)62530-5

\section{Gold-doping of carbon-supported palladium improves reduction catalysis}

Yu-Lun Fang, Kimberly N. Heck, Zhun Zhao, Lori A. Pretzer, Neng Guo, Tianpin Wu, Jeffrey T. Miller, Michael S. Wong * Rice University, USA; Argonne National Laboratory, USA; Purdue University, USA

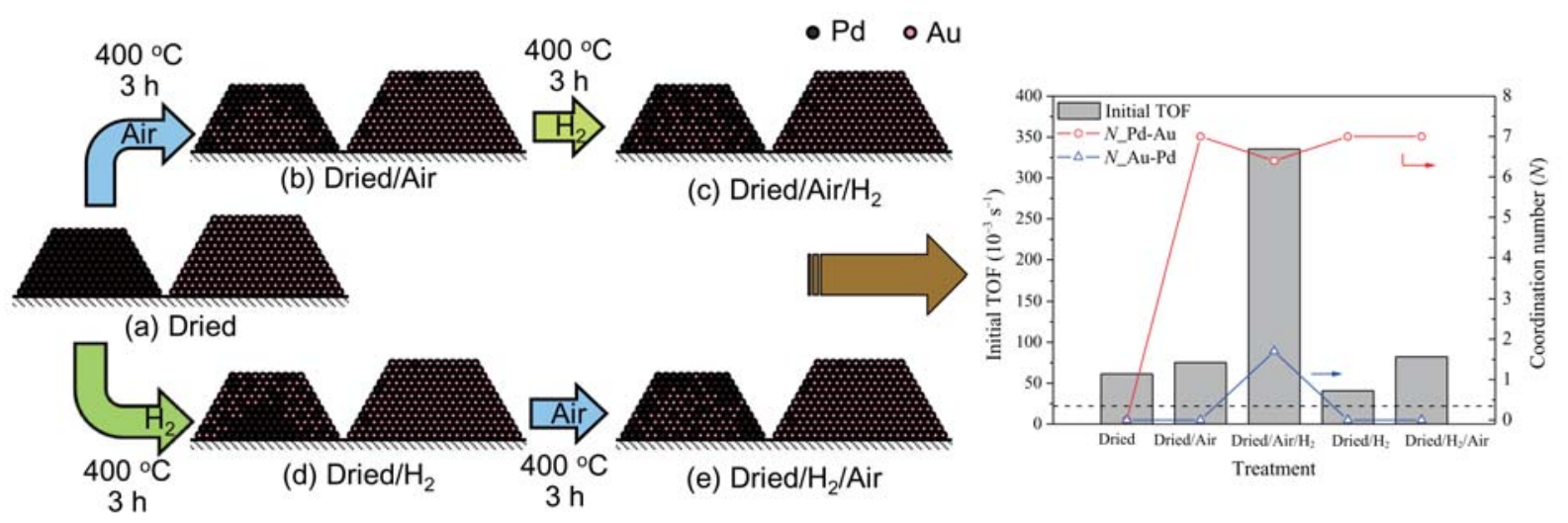

PdAu catalysts of varied bimetallic structure and activity were prepared using simple impregnation techniques on commercially available Pd on carbon catalysts. Au loading and catalyst post-impregnation treatment conditions dramatically affect structure and hydrodechlorination activity. 


\section{References}

[1] R. Ferrando, J. Jellinek, R. L. Johnston, Chem. Rev., 2008, 108, 845-910.

[2] F. Maroun, F. Ozanam, M. Magnussen, R. J. Behm, Science, 2001, 293, 1811-1814.

[3] M. S. Chen, D. Kumar, C. W. Yi, D. W. Goodman, Science, 2005, 310, 291-293.

[4] Y. L. Fang, J. T. Miller, N. Guo, K. N. Heck, P. J. J. Alvarez, M. S. Wong, Catal. Today, 2011, 160, 96-102.

[5] C. J. Baddeley, R. M. Ormerod, A. W. Stephenson, R. M. Lambert, J. Phys. Chem., 1995, 99, 5146-5151.

[6] C. J. Baddeley, M. Tikhov, C. Hardacre, J. R. Lomas, R. M. Lambert, J. Phys. Chem., 1996, 100, 2189-2194.

[7] A. W. Stephenson, C. J. Baddeley, M. S. Tikhov, R. M. Lambert, Surf. Sci., 1998, 398, 172-183.

[8] T. Wei, J. Wang, D. W. Goodman, J. Phys. Chem. C, 2007, 111, 8781-8788.

[9] V. I. Parvulescu, V. Parvulescu, U. Eudruschat, G. Filoti, F. E. Wagner, C. Kubel, R. Richards, Chem. Eur. J., 2006, 12, 2343-2357.

[10] R. J. Behm, Zeitschrift Fur Physikalische Chemie, 2009, 223, 9-36.

[11] P. A. P. Nascente, S. G. C. De Castro, R. Landers, G. G. Kleiman, Phys. Rev. B, 1991, 43, 4659-4666.

[12] B. E. Koel, A. Sellidj, M. T. Paffett, Phys. Rev. B, 1992, 46, 7846-7856.

[13] B. Hammer, Y. Morikawa, J. K. Norskov, Phys. Rev. Lett., 1996, 76, 2141-2144.

[14] A. Ruban, B. Hammer, P. Stoltze, H. L. Skriver, J. K. Norskov, J. Mol. Catal. A, 1997, 115, 421-429.

[15] A. Roudgar, A. Gross, Phys. Rev. B, 2003, 67, 033409/1-033409/4.

[16] N. Toshima, M. Harada, Y. Yamazaki, K. Asakura, J. Phys. Chem., 1992, 96, 9927-9933.

[17] S. N. Reifsnyder, H. H. Lamb, J. Phys. Chem. B, 1999, 103, 321-329.

[18] W. C. Ketchie, M. Murayama, R. J. Davis, J. Catal., 2007, 250, 264-273.

[19] M. R. Knecht, M. G. Weir, A. I. Frenkel, R. M. Crooks, Chem. Mat., 2008, 20, 1019-1028.

[20] P. Dash, T. Bond, C. Fowler, W. Hou, N. Coombs, R. W. J. Scott, J. Phys. Chem. C, 2009, 113, 12719-12730.

[21] M. G. Weir, M. R. Knecht, A. I. Frenkel, R. M. Crooks, Langmuir, 2010, 26, 1137-1146.

[22] S. M. Oxford, P. L. Lee, P. J. Chupas, K. W. Chapman, M. C. Kung, H. H. Kung, J. Phys. Chem. C, 2010, 114, 17085-17091.

[23] Y. L. Fang, K. N. Heck, P. J. J. Alvarez, M. S. Wong, ACS Catal., 2011, 1, 128-138.

[24] K. N. Heck, B. G. Janesko, G. E. Scuseria, N. J. Halas, M. S. Wong, J. Am. Chem. Soc., 2008, 130, 16592-16600.

[25] K. N. Heck, M. O. Nutt, P. Alvarez, M. S. Wong, J. Catal., 2009, 267, 97-104.

[26] M. O. Nutt, K. N. Heck, P. Alvarez, M. S. Wong, Appl. Catal. B, 2006, 69, 115-125.

[27] M. O. Nutt, J. B. Hughes, M. S. Wong, Environ. Sci. Technol., 2005, 39, 1346-1353.

[28] L. A. Pretzer, H. J. Song, Y. L. Fang, Z. Zhao, N. Guo, T. Wu, I. Arslan, J. T. Miller, M. S. Wong, J. Catal., 2013, 298, 206-217.

[29] Z. Zhao, Y. L. Fang, P. J. J. Alvarez, M. S. Wong, Appl. Catal. B, 2013, 140-141, 468-477.

[30] K. N. Heck, B. G. Janesko, G. E. Scuseria, N. J. Halas, M. S. Wong, ACS Catal., 2013, 3, 2430-2435.

[31] Z. Zhao, J. Arentz, L. A. Pretzer, P. Limpornpipat, J. M. Clomburg, R. Gonzalez, N. M. Schweitzer, T. Wu, J. T. Miller, M. S. Wong, Chem. Sci., 2014, 5, 3715-3728.
[32] Z. Zhao, J. T. Miller, T. Wu, N. M. Schweitzer, M. S. Wong, Top. Catal., 2015, 58, 302-313.

[33] H. Qian, Z. Zhao, J. C. Velazquez, L. A. Pretzer, K. Heck, M. Wong, Nanoscale, 2013, 6, 358-364.

[34] J. C. Velázquez, S. Leekumjorn, G. D. Hopkins, K. N. Heck, J. S. McPherson, J. A. Wilkens, B. S. Nave, M. Reinhard, M. S. Wong, J. Chem. Technol. Biotechnol., 2015.

[35] J. C. Velázquez, S. Leekumjorn, Q. X. Nguyen, Y. L. Fang, K. N. Heck, G. D. Hopkins, M. Reinhard, M. S. Wong, AIChE J., 2013, 59, 4474-4482.

[36] G. Schmid, A. Lehnert, J. O. Malm, J. O. Bovin, Angew. Chem. Int. Ed., 1991, 30, 874-876.

[37] G. Schmid, H. West, J. O. Malm, J. O. Bovin, C. Grenthe, Chem. Eur. J., 1996, 2, 1099-1103.

[38] M. Harada, K. Asakura, N. Toshima, J. Phys. Chem., 1993, 97, 5103-5114.

[39] Y. Wang, N. Toshima, J. Phys. Chem. B, 1997, 101, 5301-5306.

[40] C. L. Bianchi, P. Canton, N. Dimitratos, F. Porta, L. Prati, Catal. Today, 2005, 102, 203-212.

[41] J. A. Lopez-Sanchez, N. Dimitratos, P. Miedziak, E. Ntainjua, J. K. Edwards, D. Morgan, A. F. Carley, R. Tiruvalam, C. J. Kiely, G. J. Hutchings, Phys. Chem. Chem. Phys., 2008, 10, 1921-1930.

[42] L. Kesavan, R. Tiruvalam, M. H. Ab Rahim, M. I. bin Saiman, D. I. Enache, R. L. Jenkins, N. Dimitratos, J. A. Lopez-Sanchez, S. H. Taylor, D. W. Knight, C. J. Kiely, G. J. Hutchings, Science, 2011, 331, 195-199.

[43] H. Bonnemann, U. Endruschat, B. Tesche, A. Rufinska, C. W. Lehmann, F. E. Wagner, G. Filoti, V. Parvulescu, V. I. Parvulescu, Eur. J. Inorg. Chem., 2000, 819-822.

[44] R. W. J. Scott, C. Sivadinarayana, O. M. Wilson, Z. Yan, D. W. Goodman, R. M. Crooks, J. Am. Chem. Soc., 2005, 127, 1380-1381.

[45] K. D. Beard, D. Borrelli, A. M. Cramer, D. Blom, J. W. Van Zee, J. R. Monnier, ACS Nano, 2009, 3, 2841-2853.

[46] J. Rebelli, M. Detwiler, S. Ma, C. T. Williams, J. R. Monnier, J. Catal., 2010, 270, 224-233.

[47] F. Pinna, Catal. Today, 1998, 41, 129-137.

[48] J. Regalbuto, Catalyst Preparation: Science and Engineering, CRC Press, Boca Raton, FL, 2006.

[49] A. A. Herzing, A. F. Carley, J. K. Edwards, G. J. Hutchings, C. J. Kiely, Chem. Mater., 2008, 20, 1492-1501.

[50] J. C. Pritchard, Q. He, E. N. Ntainjua, M. Piccinini, J. K. Edwards, A. A. Herzing, A. F. Carley, J. A. Moulijn, C. J. Kiely, G. J. Hutchings, Green Chem., 2010, 12, 915-921.

[51] T. Ressler, J. Synchrot. Radiat., 1998, 5, 118-122.

[52] F. W. Lytle, D. E. Sayers, E. A. Stern, Physica B, 1989, 158, 701-722.

[53] K. N. Heck, M. O. Nutt, P. J. J. Alvarez, M. S. Wong, J. Catal., 2009, 267, 97-104.

[54] R. P. Schwarzenbach, P. M. Gschwend, D. M. Imboden, Environmental Organic Chemistry, Wiley, Hoboken, NJ, 2002.

[55] D. A. Bulushev, L. Jia, S. Beloshapkin, J. R. H. Ross, Chem. Commun., 2012, 48, 4184-4186.

[56] G. V. Lowry, M. Reinhard, Environ. Sci. Technol., 1999, 33, 1905-1910.

[57] K. Mackenzie, H. Frenzel, F. D. Kopinke, Appl. Catal. B, 2006, 63, 161-167.

[58] G. V. Lowry, M. Reinhard, Environ. Sci. Technol., 2000, 34, 3217-3223.

[59] S. Ordonez, B. P. Vivas, F. V. Diez, Appl. Catal. B, 2010, 95, 288-296.

[60] J. T. Miller, M. K. Neylon, C. L. Marshall, A. J. Kropf, in: J. A. Schwarz, S. E. Lyshevski, K. Putyera, C. I. Contescu eds, CRC Press, Boca Raton, FL, 2004, 3953-3972.

[61] G. Vlaic, D. Andreatta, P. E. Colavita, Catal. Today, 1998, 41, 
261-275

[62] G. Meitzner, Catal. Today, 1998, 39, 281-291.

[63] A. Carrasquillo, J. J. Jeng, R. J. Barriga, W. F. Temesghen, M. P. Soriaga, Inorg. Chim. Acta, 1997, 255, 249-254.
[64] M. W. Tew, J. T. Miller, J. A. van Bokhoven, J. Phys. Chem. C, 2009, 113, 15140-15147.

[65] Y. Shiraishi, D. Ikenaga, N. Toshima, Aust. J. Chem., 2003, 56, 1025-1029.

\title{
金掺杂对碳负载钯催化还原性能的促进作用
}

\author{
Yu-lun Fang a , Kimberly N. Heck ${ }^{\text {a }}$, Zhun Zhao ${ }^{\text {a }}$, Lori A. Pretzer ${ }^{\mathrm{b}}$, Neng Guo ${ }^{\mathrm{c}}$, Tianpin Wu ${ }^{\mathrm{c}}$, Jeffrey \\ T. Miller ${ }^{\mathrm{d}}$, Michael S. Wong a,b,e,f,* \\ a莱斯大学化工与生物分子工程系, 休斯顿 77005, 美国 \\ b莱斯大学化学系, 休斯顿77005, 美国 \\ ' 阿贡国家实验室化工科学与工程部, 阿贡 IL 60439, 美国 \\ d 普渡大学化工系, 西拉斐特, 美国 \\ e 莱斯大学土木与环境工程系, 休斯顿77005, 美国 \\ f 莱斯大学材料科学与纳米工程系, 休斯顿 77005 , 美国
}

摘要: 在许多催化应用中双金属的PdAu催化剂性能优于单金属催化剂. 科研人员对具有可控纳米结构和高活性的PdAu催 化剂进行了广泛的研究, 但该催化剂的制备需要多步且通常步骤复杂. 本文仅通过浸渍和焙烧制得了 $\mathrm{Au}$ 掺杂的负载型Pd 催化剂, 所得 $\mathrm{PdAu} / \mathrm{C}$ 催化剂用于室温水相三氯乙烯加氢脱氯反应. 当 $\mathrm{Pd}$ 和 $\mathrm{Au}$ 负载量分别为 $1.0 \mathrm{wt} \%$ 和 $1.1 \mathrm{wt} \%$ 时, 在经过干 燥、空气处理和 $\mathrm{H}_{2}$ 还原的过程后, 所制得的 $\mathrm{PdAu} / \mathrm{C}$ 催化剂活性最高, 初始转化频率(TOF)为 $34.0 \times 10^{-2} \mathrm{~mol}_{\mathrm{TCE}} \mathrm{mol}_{\mathrm{Pd}}{ }^{-1} \mathrm{~s}^{-1}$, 是 单金属 $1.0 \mathrm{wt} \% \mathrm{Pd} / \mathrm{C}$ 催化剂TOF $\left(2.2 \times 10^{-2} \mathrm{~mol}_{\mathrm{TCE}} \mathrm{mol}_{\mathrm{Pd}}{ }^{-1} \mathrm{~s}^{-1}\right)$ 的15倍以上. X射线吸收光谱结果表明, 金的加入避免了 $400^{\circ} \mathrm{C}$ 焙烧时Pd的氧化. 本文还提出了可能的催化剂纳米结构演变路径, 以解释所观察到的催化现象.

关键词: 双金属催化剂; 钯; 金; 纳米结构; X射线吸收光谱; 扩展X射线吸收精细结构; 加氢脱氯; 三氯乙烯

收稿日期: 2016-05-28. 接受日期: 2016-08-14. 出版日期: 2016-10-05.

*通讯联系人。电话: +1-713-348-3511; 传真:+1-713-348-5478; 电子信箱: mswong@rice.edu

基金来源：美国国家科学基金会(EEC-0647452); 维尔许基金(C-1676).

本文的英文电子版由Elsevier出版社在ScienceDirect上出版(http://www.sciencedirect.com/science/journal/18722067). 